\title{
Diversification of production of biofuel - as the basis of maintenance of food, power, economic and environmental safety of Ukraine
}

\author{
Kaletnik G. \\ Vinnytsia national agrarian university, Soniachna Str., 3, Vinnytsia, 21008, Ukraine; e-mail: \\ rector@vsau.org
}

The purpose. To carry out complex research in scientific maintenance and to develop the Concept of power autonomism of agroindustrial production and village territories which will be based on effective production and use of biomass. Methods. Monographic, design, mathematical-statistical. Results. By economic and social necessity of formation and development of market of biofuel of Ukraine there are some reasons, beginning from power safety, diversification of national production, support of innovations and finishing with economic efficiency-social efficiency of development of market of biofuel on the basis of high motivation of growth of agrarian sector, positive social shear concerning growth of busy condition of agricultural population and environmental safety owing to renewed energy sources. Conclusions. Dynamic production of biofuel demands creation of market of power crops (raw material for its production) and use of agricultural lands, suitable for growing power crops, provided that the level of production of agricultural products on the food purposes will not decrease. It will help Ukraine to lower dependence on import of energy carriers, will shut down its transformation to raw appendage, will enable to recycle inside a scale resource, having gained thus of hundred thousand work stations, growth of incomes of citizens and state budget. Production of biofuel at the given stage of development of state acts as one of the basic accelerants of new global trends in agribusiness industry of Ukraine which will promote its stable development.

Key words: alternative energy sources, energy balance, food safety, agriculture, prices disparity, diversification of production.

https://doi.org/10.31073/agrovisnyk201811-21

The development of a market economy in Ukraine depends to a large extent on solving the uninterrupted supply of energy resources to all sectors of the national economy without exception. Under market conditions, increasing the national wealth of our country, improving the living standards of the population and its socioeconomic status will largely depend on the rational consumption of energy resources. Due to this the process of improving the use of energy sources and alternative forms of energy becomes of special urgency. The complex of energy saving measures should be carried out in the context of the practical realization of scientific, economic, legislative, organizational, technical, technological and environmental constituents aimed at the rational consumption of energy resources with the gradual increase and introduction into the economic turnover of the most economically feasible sources of energy, where the biofuels should have the priority place.

Analysis of recent research and publications. The research of the biofuel market, the development of scientific principles for the diversification of the development of the production of alternative energy sources in all spheres of economic life of Ukraine, scientific and technical support for the energy autonomy of agroindustrial production on the basis of the effective use of renewable energy sources in order to ensure the energy autonomy of the agro-industrial complex is covered in the works of such scientists as $\mathrm{V}$. Adamchuk [7] M. Carneiro

[14],

M. Guo [15], I. Kyrylenko [10], Yu. Lupenko, M. Malika, V. Mesel-Veselyak, S. Oliynychuka, B. Panasyuk [12], M. Roik [9], M. Sychevsky, L. Khomychak, O. Shpykuliak, O. Shpychak [13] and others. However, not all issues in this area are finally resolved.

A number of factors causing the necessity of production and consumption of biofuels in Ukraine, in particular: dependence on the import of energy carriers; exhaustion of fossil fuels; rising prices for fuel resources; increase of communal tariffs; deterioration of the ecological situation; availability of natural resource potential; excessive exports of agricultural products, etc.

The provision of biofuels production will help to stabilize the development of the agro-industrial complex 
by creating new jobs, providing additional revenues to the state budget, improving the ecological situation, providing energy, economic independence and food security.

The purpose of the study is a comprehensive research on scientific support and the development of the Concept for the energy autonomy of agro-industrial production and rural areas, based on the efficient production and use of biomass.

Research results. Power engineering is the basis for the development of each state. According to the Energy Balance 2017, such elements as natural gas (31\%), coal and peat (32\%), nuclear power $(22 \%)$ and petroleum fuels $(10 \%)$ have the largest share in the structure of Ukraine's energy consumption. For a long period, the share of renewable energy in Ukraine varies within 3\% [1, 2].

At the same time, there are discriminatory tendencies in the cost of supply and intermediary services and products for the agro-industrial complex and significant disparity in prices for energy, industrial and agricultural products. According to the Ministry of Agrarian Policy and Food of Ukraine, the average annual demand for agro-industrial complex in petroleum products is on average: diesel fuel is 2 million tons, gasoline - about 600 thousand tons [3].

Table 1. The disparity of prices for agricultural products and traditional energy resources in the world, 1960-2018

\begin{tabular}{|c|c|c|c|c|c|c|c|c|c|c|}
\hline Indicator & 1960 & 1970 & 1980 & 1990 & 2000 & 2010 & 2015 & $\begin{array}{c}2018 \\
\text { (Januar } \\
\text { y-July) }\end{array}$ & $\begin{array}{c}2018 \\
- \\
1990, \\
\text { at } \\
\text { times }\end{array}$ & $\begin{array}{c}2018 \\
- \\
1960 \\
\text {, at } \\
\text { time } \\
\text { s }\end{array}$ \\
\hline \multicolumn{11}{|c|}{ World price trends } \\
\hline $\begin{array}{l}\text { Average } \\
\text { weighted spot } \\
\text { price of crude oil, } \\
\text { UAH /t }\end{array}$ & 12,0 & 8,9 & 270,3 & 167,7 & 207,0 & 579,5 & 372,1 & 413,2 & 2,46 & 34,4 \\
\hline $\begin{array}{l}\text { Export price of } \\
\text { wheat, USD/t }\end{array}$ & 58,0 & 54,9 & 172,7 & 135,5 & 114,1 & 223,6 & 204,5 & 229,9 & 1,69 & 3,9 \\
\hline $\begin{array}{l}\text { Price of raw } \\
\text { sugar according } \\
\text { to ISO, } \mathrm{UAH/t}\end{array}$ & 66,2 & 82,2 & 631,6 & 276,7 & 180,4 & 469,3 & 296,3 & 319,8 & 1,15 & 4,8 \\
\hline \multicolumn{11}{|c|}{ Number of products corresponding to units of crude oil, tons } \\
\hline Wheat & 0,21 & 0,16 & 1,56 & 1,24 & 1,81 & 2,59 & 1,82 & 1,79 & 1,44 & 8,5 \\
\hline Sugar & 0,18 & 0,11 & 0,43 & 0,61 & 1,15 & 1,23 & 1,26 & 1,39 & 2,27 & 7,7 \\
\hline
\end{tabular}

Source: table compiled by the author according to the data of International Sugar Organization, Independent Statistics and Analysis U.S. Energy Information Administration and own investigation and calculations [4, 5]

At the price of 2000, in order to buy such quantity of diesel fuel and gas, the expenses amounted to 4 billion 500 million UAH In 2014 - 30 billion 985 million UAH. In 2017 - 56 billion 720 million UAH. Thus, the expenses of agrarians increased by 8 times in 14 years, while the price of sugar beet, grain, meat and milk sales increased by 3.3-4.1 times. For each year, fuel consumption grew by UAH 1.8 billion, while revenue was only a half. Obviously, such a price disparity leads to a decrease in the profitability of agricultural production. Interestingly, for a peasant, the price for wheat, barley, milk, meat increases by an average of $7-12 \%$ annually, while the price for bread, milk, butter, and sausage in trade - by $32-45 \%$ annually (Table. 2) [2]. 
Table 2. Comparison of prices of sales of products by agricultural and processing enterprises

\begin{tabular}{|c|c|c|c|c|}
\hline \multicolumn{2}{|c|}{$\begin{array}{c}\text { Average prices of products sold by } \\
\text { agricultural enterprises, UAH / }\end{array}$} & $\begin{array}{c}\text { Average prices of sales by } \\
\text { enterprises of processing industry, } \\
\text { UAH / }\end{array}$ & $\begin{array}{c}\text { Share of prices of } \\
\text { agricultural enterprises at } \\
\text { retail price, } \%\end{array}$ \\
\hline Wheat & 6679 & Wheat flour & 13340 & 50.01 \\
\hline Oil seed & 9673 & Sunflower oil & 35670 & 25.9 \\
\hline Farm animals & 33290 & Beef & 118930 & 27.99 \\
\hline Raw milk & 8033 & $\begin{array}{c}\text { Pasteurized milk } \\
(2.6 \%)\end{array}$ & 22130 & 36.29 \\
\hline
\end{tabular}

Source: the table is formed by the author according to the data of the State Statistics Service of Ukraine and own calculations [2]

For example, in order to buy 1 ton of diesel fuel in 1990, the peasants were supposed to sell 0.2 tons of grain, in 2000 - 3 tons, in $2010-5.9$ tons, and in $2017-6.6$ tons, that is, the fuel, in grain equivalent, has risen in price by 33 times for 26 years for agrarians. The similar trend is observed with gasoline, natural and liquefied gas (Table 3) [2, 6].

Table 3. Comparison of the quantity of wheat and sugar to be sold for the purchase of a unit of fuel and mineral fertilizers in Ukraine

\begin{tabular}{|c|c|c|c|c|c|c|}
\hline Indicator & 1990 & 2000 & 2010 & 2015 & $\begin{array}{c}2018 \\
\text { (January } \\
\text { - July) }\end{array}$ & $\begin{array}{c}2018 \text { - } \\
1990 \text {, at } \\
\text { times }\end{array}$ \\
\hline \multicolumn{7}{|c|}{ Wholesale prices, UAH, per 1 ton (excluding VAT) } \\
\hline Diesel fuel & 145 & 1873 & 5928 & 14970 & 27200 & $\mathrm{x}$ \\
\hline Ammonium nitrate & 70 & 420 & 1560 & 5718 & 8600 & $\mathrm{x}$ \\
\hline \multicolumn{7}{|c|}{ Prices of agricultural enterprises, UAH, per 1 ton (without VAT) } \\
\hline Wheat & 272 & 487 & 1086,1 & 2796,2 & 6750 & $\mathrm{x}$ \\
\hline Sugar & 780 & 1579,8 & 5717,3 & 9633 & 14390 & $\mathrm{x}$ \\
\hline \multicolumn{7}{|c|}{ Number of products to be sold for the purchase of a unit of resources, tons } \\
\hline \multicolumn{7}{|c|}{ Wheat } \\
\hline Diesel fuel & 0,53 & 3,85 & 5,46 & 5,35 & 4,03 & 7,6 \\
\hline Ammonium nitrate & 0,26 & 0,86 & 1,44 & 2,04 & 1,27 & 4,8 \\
\hline \multicolumn{7}{|c|}{ Sugar } \\
\hline Diesel fuel & 0,19 & 1,19 & 1,04 & 1,55 & 1,89 & 9,9 \\
\hline Ammonium nitrate & 0,09 & 0,27 & 0,27 & 0,59 & 0,6 & 6,7 \\
\hline
\end{tabular}

Source: the table is formed by the author according to the data of the State Statistics Service of Ukraine and own calculations $[2,6]$

Agriculture in the Ukrainian economy for this period is the most stable segment and provides one third of export revenues, and its production is more than 14\% of GDP. Under these conditions, the state does not have the resources to significantly support the development of agro-industrial production at the expense of other industries. At the same time, agro-industrial production while addressing the food security of the state, is entirely dependent on energy imports of imported origin, which is unacceptable and strategically dangerous [2].

According to the results of the analysis of the world and domestic experience in solving the problem of energy replacement, it is easy to conclude that the prospective is the relocation of domestic refuelers to the use of energy sources that are derived from renewable sources. In the natural and climatic conditions of Ukraine, the use of energy produced by bioenergy technologies is the most stable and managed for implementation in modern technological processes of agricultural production. They are based on the most advanced mechanism of solar energy utilization - photosynthesis. By converting the corresponding biosources to special technologies, they receive solid, liquid and gas biofuels and use them respectively for 
the production of thermal energy for the heating of agricultural drying rooms or as fuel in internal combustion engines in the form of biomethane, bioethanol and biodiesel [7].

Unsatisfactory state control over monopolists even leads to such distortions, when the price of barrel of oil falls three times, and the price of diesel fuel and gasoline in Ukraine, at best, does not increase for a certain period, but does not decrease (Fig. 1) [6].

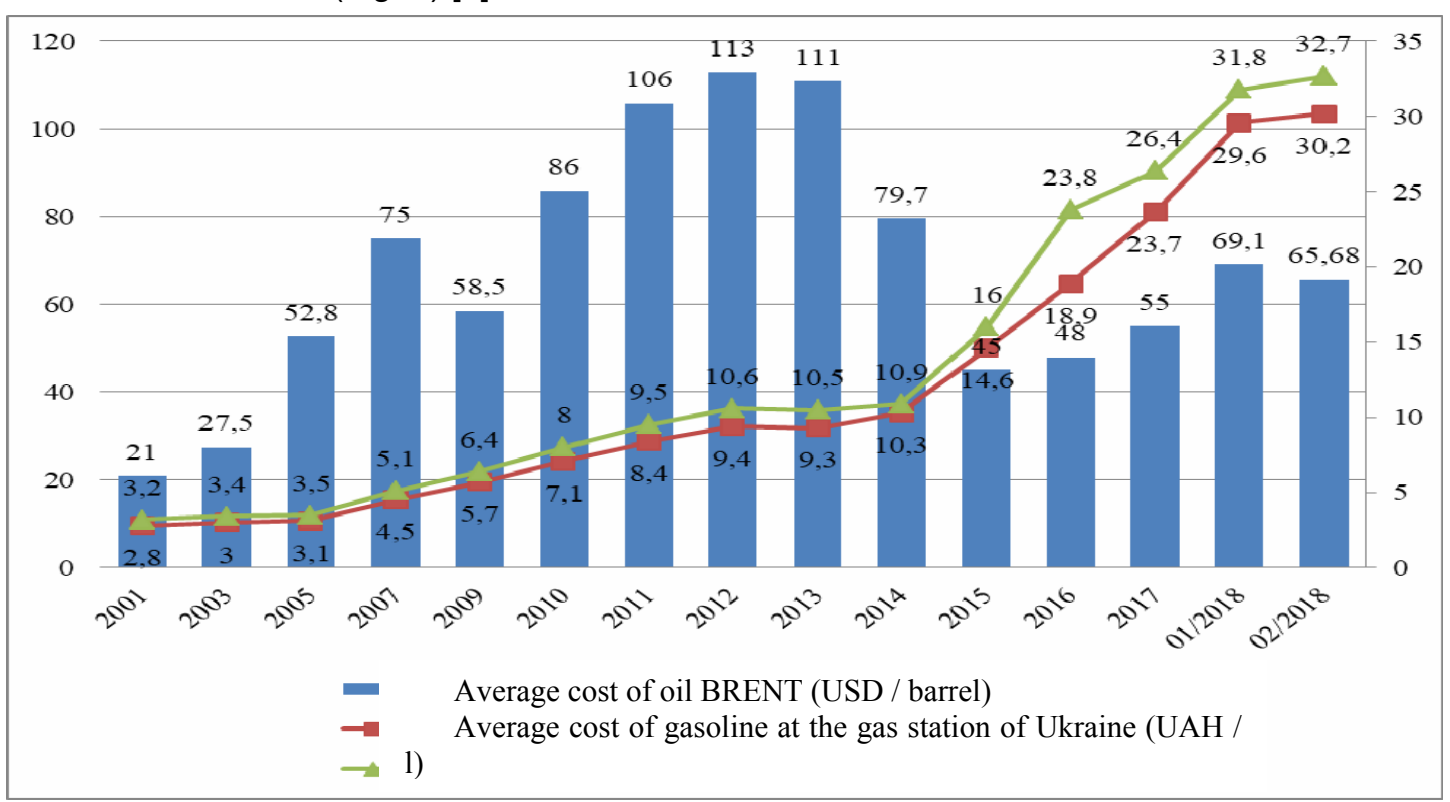

Fig. 1. The correlation of the dynamics of prices for oil, gasoline A-95 and diesel, 2001-2018

That is why, given the problems encountered at the present stage of the state's development, biofuel production is one of the decisive catalysts for new global trends in the agro-industrial complex of Ukraine, which will contribute to its stable development.

Increasing fuel prices negatively affects the interest in growing crops, especially labour-intensive ones, which need to spend a huge amount of petroleum products. Today we have the opportunity and the need to equip our processing industry with the processing industry, the individual sector and all farms that produce crop and livestock products with the aim of establishing biofuel production there.

We must understand for ourselves and conclude that it is more profitable for us: to be a raw material appendage or to recycle such a large resource at our disposal, thus having hundreds of thousands of jobs, incomes of its citizens and the state budget, and sharply reduce the dependence of the state on imports of energy resources. By exporting agricultural raw materials abroad we give the opportunity to benefit other countries, and from this the Ukrainian economy does not receive anything [13].

The solution of the problem of dynamic production of biofuels requires the creation of a market for energy crops as raw materials for its production, the use of agricultural land suitable for growing energy crops without reducing the level of agricultural production for food purposes.

In 2017-2018 MY Ukraine ranked 6th in the world's production of corn with an annual production of 30 million tons, of which the biggest share was exported. 24 million tons of corn $(80 \%)$ of 30 million tons were exported. For comparison, the leader in the production of corn was the United States - 361.46 million tons, but the volume of exports was only $15.6 \%$ (56.5 million tons) (Table 4) [8]. 
Table 4. Diversification of production of biofuel - as the basis of maintenance of food, power, economic and environmental safety of Ukraine TOP-10 corn producers and exporters in the world (2017-2018 MY)

\begin{tabular}{|c|c|c|c|c|c|c|}
\hline Rank & Country & $\begin{array}{c}\text { Production, } \\
\text { mln. t }\end{array}$ & Exporter & $\begin{array}{c}\text { Export } \\
\text { volume, } \\
\text { mln. t }\end{array}$ & $\begin{array}{c}\text { Export } \\
\text { volume, } \\
\text { billion dollars }\end{array}$ & $\begin{array}{c}\% \text { World } \\
\text { total }\end{array}$ \\
\hline 1 & USA & 361.46 & USA & 56.5 & 9.6 & 32.3 \\
\hline 2 & China & 225.0 & Brazil & 31.0 & 4.6 & 15.6 \\
\hline 3 & Brazil & 96.0 & Argentina & 27.0 & 3.9 & 13.1 \\
\hline 4 & Argentina & 41.0 & Ukraine & 24.0 & 3.0 & 10.1 \\
\hline 5 & Ukraine & 30.0 & France & - & 1.4 & 4.8 \\
\hline 6 & Mexico & 26.0 & Russia & 4.0 & 0.887 & 3 \\
\hline 7 & India & 26.0 & Hungary & - & 0.882 & 3 \\
\hline 8 & Canada & 14.8 & Romania & - & 0.826 & 2.8 \\
\hline 9 & South Africa & 14.0 & Mexico & 1.5 & 0.488 & 1.6 \\
\hline 10 & Russia & 12.0 & South Africa & 2.2 & 0.473 & 1.6 \\
\hline
\end{tabular}

Source: The table is generated by the author according to World's Top Export [8]

Although the US possesses the largest oil reserves in the world, with each passing year, the volume of corn processing for bioethanol is increasing. If in 2000 the United States processed only $10 \%$ of gross corn crop on bioethanol, in 2013 this volume was more than $40 \%$, that is, $130-135 \mathrm{mln}$. tone. In this case, the byproduct of processing, that is, the protein part of the cereal grains is used to fatten animals and produce milk and meat [9].

In order to reduce the shortage of petroleum products abroad, Ukraine exported grain corn is partially processed on bioethanol. At the same time, we annually buy more than half of the demand for light petroleum products and more than 25 billion $\mathrm{m} 3$ of natural gas. Therefore, we need to switch to more effective ways to use the cultivated agricultural products.

The search for an effective solution of the problem of energy replacements is now being actively pursued in the advanced countries of the world. For example, EU countries have adopted a directive on the prohibition of coal use after 2030. And Sweden, Norway, Germany and other European countries adopted a plan for the development of alternative energy, which provides for the rejection of the use of natural fossil fuels after 2050 [15]. Brazil already annually produces 20 billion, and the United States is almost 30 billion litres of bioethanol. The current level of development of bioethanol production technologies and technical means for their implementation has reached a high level, in particular, in Brazil, from sugar cane, collected from 1 hectare, produce 7500 litres of bioethanol, in the USA from corn - 3800 litres, and in countries of Europe from sugar beets - 5500 litres. It deserves a positive assessment of the Czech experience in the production and use of biodiesel, and the USA, Germany, China and India in the production of biogas. If in the 1950-1970s the practical output of biogas in comparison with the theoretically possible was $20-30 \%$, now, thanks to the improvement of technologies and technical means, this indicator is increased to $95 \%$ [10, 14].

The part of corn which is subsequently exported would be much more expedient to grow silage and produce biogas from it, as is the case with Germany and China, which is the leader in the number of biogas plants in the world.

The production of biogas in individual biogas reactors has particular importance in China, where more than 35 million biogas plants operate now, which utilize all waste from livestock and crop production through the conversion to biogas. Recycled waste is no longer dangerous for the environment, but instead it is possible to obtain environmentally friendly biogas and organic fertilizers. Thus, China today, producing livestock products in the individual sector, simultaneously receives more than 20 billion $\mathrm{m} 3$ of biogas [9].

Now, in Germany, there are about 2 thousand large biogas plants producing biogas from corn silage. Compared with other energy crops, corn silage benefits from lower costs of growing and storing. In addition, the production of biogas from corn silage is marked by a reduction in greenhouse gas emissions and high fuel economy. Also, corn can be stored in the field for up to one year with low fuel losses in dry mass. In 
recent years, the average grain yield of silage corn in agroformations of Ukraine is $350-360 \mathrm{c} / \mathrm{ha}$. Thus, for 2 million hectares of corn from which the grain is exported, we can produce up to 26 billion $\mathrm{m} 3$ of biogas in Ukraine, thus solving the problem not only of dependence on the import of natural gas, but also to create additional jobs and revenues to the state budget .

Table 5. Potential output of biogas and biomethane from bioenergetic plants

\begin{tabular}{|c|c|c|c|c|c|c|}
\hline Culture & $\begin{array}{c}\text { Potential of } \\
\text { sown area, } \\
\mathrm{mln} \text {.ha }\end{array}$ & $\begin{array}{c}\text { Yield } \\
\text { capacity, } \\
\mathrm{t} / \mathrm{ha}\end{array}$ & $\begin{array}{c}\text { Biogas } \\
\text { output, } \\
\mathrm{m} 3 / \mathrm{t}\end{array}$ & $\begin{array}{c}\text { Biomethane } \\
\text { output, } \\
\mathrm{m3} / \mathrm{t}\end{array}$ & $\begin{array}{c}\text { Biogas } \\
\text { output, } \\
\text { billion } \\
\mathrm{m} 3 / \\
\text { year }\end{array}$ & $\begin{array}{c}\text { Bio- } \\
\text { methane } \\
\text { output, } \\
\text { billion } \mathrm{m} 3 \\
\text { year }\end{array}$ \\
\hline $\begin{array}{c}\text { Corn for } \\
\text { silage }\end{array}$ & 2 & 80 & 200 & 106 & 32 & 17 \\
\hline Sugar beets & 0,5 & 70 & 130 & 72 & 4,6 & 2,5 \\
\hline $\begin{array}{c}\text { Sugar } \\
\text { Sorghum }\end{array}$ & 0,5 & 80 & 220 & 110 & 8,8 & 4,4 \\
\hline Total & 3,5 & & & & 45,4 & 23,9 \\
\hline
\end{tabular}

Source: the table is formed by the author according to the data of the State Statistics Service and own calculations and own calculations [2]

The cost of corn for silage in 2014 is $160 \mathrm{UAH} / \mathrm{t}$. Taking into account that the output of biogas from 1 ton of silo is about $250 \mathrm{~m} 3$, the cost of $1000 \mathrm{~m} 3$ of biogas made from silage maize will be no more than $\$ 100$. Another problem of the agroindustrial complex is the instability of the beet sugar complex functioning in connection with the fluctuation of prices in the market $[2,12]$.

\section{Conclusions}

Consequently, the development of production and consumption of biofuels in Ukraine, whose economy is $80 \%$ dependent on oil imports, is relevant and strategically important. We need, as a country with a huge potential of the raw material base for the production of biological fuels, to deal with it at the state level and in large scale.

For example, you can take Brazil, which from import-dependent turned into a country that provided its needs for petroleum products with biofuels, and today does not buy any barrel of oil. The production of liquid biofuels from biomass would solve the problem not only of energy security but also stabilize the agrarian sector of the economy. This is also relevant for Ukraine, especially for the sugar beet industry.

Discussions conducted in the community on the feasibility of using agricultural raw materials for the production of energy in the face of food shortages in some countries. For us, there should be an example of the USA, which annually processes over 135 million tons of corn for bioethanol, thus solving energy security for distant future.

The recommendations of certain foreign experts regarding immorality of biomass processing for fuel should be perceived as customary and harmful to our national interests. After all, in the world, each country, endowed with certain natural resources (oil, gold, and land), provides a decent standard of living for its citizens, using their strategic capabilities.

\section{References}

1. Adamchuk V.V., Myronenko V.H., Lukianets V.O. et al. (2013). Systema orhanizatsiinykh zakhodiv ta tekhniko-tekhnolohichnykh zasobiv teplozabezpechennia silskykh terytorii na osnovi mistsevoho biopalyva. [System of organizational measures and techno-technological means of heating of rural areas on the basis of local biofuel]. Mekhanizatsiia ta elektryfikatsiia silskoho hospodarstva. Hlevakha, Vyp. No 98. P. $308-$ 320. [In Ukrainian].

2. Guo M., Song W., Buhain J. (2015). Bioenergy and biofuels: History, status, and perspective. Renewable and Sustainable Energy Reviews. V. 42. P. 712 - 725. 
3. Carneiro M.L. (2017). Potential of biofuels from algae: Comparison with fossil fuels, ethanol and biodiesel in Europe and Brazil through life cycle assessment (LCA). Renewable and Sustainable Energy Reviews. V. 73. P. $632-653$.

4. Kyrylenko I.H., Demianchuk V.V., Andriushchenko B.V. (2010). Formuvannia rynku ukrainskoho biopalyva: peredumovy, perspektyvy, stratehiia. [Formation of the Ukrainian biofuel market: preconditions, prospects, strategy]. Ekonomika APK. No 4. P. 62. [In Ukrainian].

5. Panasiuk B.la. (2015). Innovatsiine buriakotsukrove pidpryiemnytstvo - stabilnyi shliakh do enerhonezalezhnoi ekonomiky. [Innovative Beet Sugar Entrepreneurship - A Stable Way to an Energy-Free Economy]. Ekonomika. Finansy. Menedzhment: aktualni pytannia nauky i praktyky. No 3. P. 9 - 14. [In Ukrainian].

6. Roik M.V., Kurylo V.L., Hanzhenko O.M., Humentyk M.la. (2013). Bioenerhetyka v Ukraini: stan ta perspektyvy rozvytku. [Bioenergy in Ukraine: the state and prospects of development]. Bioenerhetyka. No 1. P. 5 - 10. [In Ukrainian].

7. Shpychak O.M., Bodnar O.V. (2015). Enerhetychnyi pidkhid shchodo otsinky transformatsii v silskomu hospodarstvi cherez pryzmu fiziokratychnykh pohliadiv u konteksti innovatsiinykh protsesiv. [Energy Approach to Assessing Transformations in Agriculture through the Perspective of Physiocratic Views in the Context of Innovation Processes]. Ekonomika APK. No 10. P. 5 - 16. [In Ukrainian].

8. Ofitsiinyi sait Derzhavnoho ahentstva $z$ enerhoefektyvnosti ta enerhozberezhennia Ukrainy. [Official site of the State Agency for Energy Efficiency and Energy Conservation of Ukraine ]. URL: http://saee.gov.ual [In Ukrainian].

9. Ofitsiinyi sait Derzhavnoi sluzhby statystyky Ukrainy. [Official site of the State Statistics Service of Ukraine]. URL: http://www.ukrstat.gov.ua/ [In Ukrainian].

10. Ofitsiinyi sait Ministerstva ahrarnoi polityky ta prodovolstva Ukrainy. [Official site of the Ministry of Agrarian Policy and Food of Ukraine]. URL: http://minagro.gov.ua/ [In Ukrainian].

11. Official site of International Sugar Organization. URL: https://www.isosugar.org/prices.php [In Ukrainian].

12. Official site of Independent Statistics and Analysis U.S. Energy Information Administration. URL: https://www.eia.gov/ [In Ukrainian].

13. Ofitsiinyi sait Naftovoi Asotsiatsii Ukrainy. [Official site of the Petroleum Association of Ukraine]. URL: http://oilers.org.ua

14. Official site of World's Top Export. URL: http://www.worldstopexports.com/corn-exportscountry/ [In Ukrainian].

15. Kaletnik G., Prutska O., Pryshliak N. (2014). Resource potential of bioethanol and biodiesel production in Ukraine. Visegrad Journal on Bioeconomy and Sustainable Development.. No 1. P. 9 - 12. 